Article

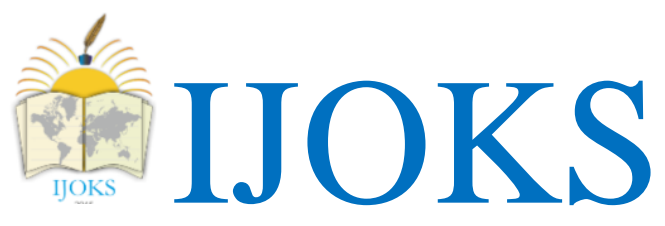

International Journal of Kurdish Studies

(ISSN:2149-2751)

$5(1)$, pp. $312-327$

http://www.ijoks.com

\title{
Uzaktan Eğitim Alaninda Ana Dili Arapça Olmayanlara Arapça Öğretiminde, Sosyal Medya Faktörü
}

\section{Hasan AKREŞ ${ }^{1}$}

Received: Jan 01, 2019 Reviewed: Jan 12, 2019 Accepted: Jan 14, 2019

\section{$\ddot{O} z$}

Gelişen teknoloji, hayatın bütün alanlarına girip çok büyük etki ve değişimler meydana getirmiştir. Öyle ki artık herhangi bir alanda bu gelişme ve ilerlemeden bahsetmemek mümkün olmamakla beraber, bu gelişimsel değişimlerin ortaya çıkmasında bilgi teknolojilerinin (internet, bilgisayar vb.) rolüne değinmek, genel olarak kısmen, özel olarak ta genel bir etki alanı olan sosyal medya ağlarının etkisini vurgulamak gerekmektedir. Kullanıcının nesnel ve öznel çeşitli ihtiyaçlarını karşılamak için rahatça gezinebileceği alanlar olan sosyal medya ağları birçok özelliğe sahiptir. Özgür bir paylaşım ve diyalog alanı oluşturduğu, zaman, mekân ve ulaşım sorunlarının söz konusu olmadığı, erişilebilirliğinin kolaylık ve basitliği gibi özelliklerden kaynaklı toplum hayatının tüm noktalarına nüfuz etmiş, kullanılabilirlik oranı çok yüksek bir platformdur.

Eğitim sektörü de teknolojik gelişmelerden oldukça etkilenen ve bu çerçevede değişimden faydalanan alanlardandır. Arapça öğretimi için Bilgi ve İletişim Teknolojilerini (BİT) kullanmak Arap dili öğrenme becerilerini geliştirme açısından büyük bir öneme sahiptir. Gelişen teknoloji, internetin ve özellikle Sosyal Medya'nın yabancı dil eğitimi alanında çok daha işlevsel ve aktif olabilmesine olanak tanımıştır. Yeterli olmamakla beraber, farklı Sosyal Medya uygulamaları kullanıcı veya üyelerine katılımın gerekli olduğu dil eğitimi programları sunmaktadır. Bu durumun son yıllarda özellikle Arapça dili eğitiminde yaygınlaşması, okuma, yazma, konuşma ve dinleme gibi dil öğreniminde kıstas olan dört dil becerilerinin de kullandırılması, dil eğitimi alanında Sosyal Medya kullanımını popüler bir hale getirmiştir. Bu sebeplerden hayatımızda önemli bir zaman ve mekân teşkil eden Sosyal Medya, Uzaktan Eğitim programlarının odağına girmektedir.

Bu makale, Sosyal Medya aracılığı ile Arapça eğitiminde umut verecek bir gelecek inşa etmek adına hazırlık niteliğindeki bu çabanın, güncel teknolojik gelişmelerden haberdar, dijital çağ ile uyumlu, eğitimsel ihtiyaçları karşılayabilen, özgün ve uyarlanabilir stratejiler oluşturması amacıyla kaleme alınmıştır.

Anahtar kelimeler: Sosyal paylaşım, Arapça, Dil, Eğitim

\footnotetext{
${ }^{1}$ Ass. Prof. Dr., Batman University, Faculty of Islamic Sciences, Department of Arap Language and Rhetoric ( Dr. Öğr. Üyesi, Batman Üniversitesi, İslami ilimler Fakültesi, Arap Dili ve Belagatı Anabilim Dalı),

E-mail: hassan akrish@yahoo.com, ORCID NO : https://orcid.org/0000-0003-4740-9180
} 


\title{
The factor of the Social Media in Arabic education for the Non-Arabic speakers
}

\begin{abstract}
The technological revolution has had a large influence in nearly all spheres of life. Whenever a development or enhancement in any field is mentioned, it is necessary to refer to the role of informatics technologies (internet) in its emergence and spread in general terms, and in some cases, to emphasize the effects of social media in particular. Social media sites, where users can comfortably browse as well as meet their needs and desires, possess a number of important properties. Among the other properties in question, interactive, flexible, participatory, and comprehensive have a different place; it shows that social sharing networks have been extensively used in all stages of life.

The education sector is also one of the fields that has been highly affected by technilogical developments. Since the use of social media became widespread, distant education has been influenced to a significant degree. Information and communication technology (ICT) is having a major impact in terms of improving Arabic learning, and language skills more generally. One of the latest trends used in foreign language education is the use of social networks. WhatsApp plays an important role in our everyday lives nowadays; it also helps us in the field of education. WhatsApp offers collaborative language teaching capabilities alongside various other features. Itcan be used to develop all four language skills (reading, writing, speaking, and listening). This paper serves to develop original strategies that are authentic and work well in the digital age in the hope of contributing to a promising future in education through social sharing sites.
\end{abstract}

Key words: Social media, Arabic, Language, Education

\section{Recommended citation:}

Akreş, H. (2019). Uzaktan Eğitim Alaninda Ana Dili Arapça Olmayanlara Arapça Öğretiminde, Sosyal Medya Faktörü. International Journal of Kurdish Studies 5 (1), 312 - 327 DOI: $10.21600 /$ ijoks.506385

\section{Giriş}

William Claster'a göre insanlar, okuduklarının \%10’unu, duyduklarının \%20'sini, gördüklerinin \%30'unu, görme ve işitme yetilerini birlikte kullanarak algıladıklarının \%50'sini, başkaları ile tartıştıklarının \%70'ini, deneyimlediklerinin \%80'ini ve diğer bir şahsa aktardıkları bilgilerin \%95'ini öğrenmektedirler. ${ }^{\mathrm{i}}$

$\mathrm{Bu}$ tespit bizlere görülebilir, işitilebilir ve de katılım koşullarının var olduğu sanal eğitim alanları sağlandığında, deneyimleyerek öğrenmenin, hem alıcı hem de verici olma durumundan kaynaklı oluşacak tecrübenin en iyi eğitim ve öğretim metodu olduğunu göstermektedir. Günümüzde Sosyal Medya, bu yöntemin uygulanabilirliği açısından tüm parametreleri barındırmakla beraber, ideal öğretici, eğitici ve deneyimlenmiş kalıcı bilgi oluşturacak bir aracı olma açısından ciddi potansiyele sahiptir. 
$\mathrm{Bu}$ gelişme ve tespitler 1şı̆̆ında geleneksel eğitim metotlarının tekrardan değerlendirilmesi gerekmekle beraber eğitimde birincil taraf olan eğitmenlerin ve eğitim modelinin güncel, uyum sağlayan bir şekle revize edilmesi gerekliliği acil bir ihtiyaç olarak ortaya çıkmaktadır. Eğiticinin bir klişe olarak öğrencileri Sosyal Medyanın olumsuz ve zararlı yanlarına odaklamaktansa, geniş uzaktan eğitim sahasında var olan Sosyal Medya uygulamaları, sohbet odaları ve forumlara, bilgi alışverişi ve ders ortamları oluşturma adına, adres verip yönlendirerek sürece dâhil etmelidir. Dr. İbrahim Amir el-Kandelci'nin vurguladığı gibi Sosyal Medya Ağları, eğitmenler ve uzaktan eğitime katılanlar arasında akademik faaliyet ilişkilerinin aktifleştirilmesinde kullanılmalıdır. ${ }^{\text {ii }}$

Yeni yöntemlerin uygulanmasıyla beraber uzaktan eğitim, öğretici ve öğrenci arasında klasik mesaj alışverişine dair bilindik yöntemler ile gerçekleşen bilgi aktarımı şeklinde özetlenemeyecek geniş bir çerçeveye sahip olmaktadır. Bu bağlamda öğrencinin verileri edinme biçimi de değişmekte, Sosyal Medya, kendisine daha üstün öğrenme imkânı sağlayan fırsat ve alternatifler sunmaktadır. Derslere katılanlar salt bir alıcı konumundan çıkıp aktif bir öğrenci olmakta, eğitici de dikte ettiren pozisyonunda kalmayarak yönlendirici sıfatını da kazanmaktır. Bahsedilenlerden hareketle eğitim realitesine dair modern yönelimlerde farklı bir bakış açısı benimsenmekte ve öğrenmenin içeriğinin özüne ek olarak, içeriğin kullanımı, öğrencinin ve öğretmenin pozisyonu ile ilgili olduğu görülmektedir.

\section{Eğitim Sürecinde Sosyal Medya Uygulamalarının Önem ve Özellikleri}

Sosyal medya araçlarının vakit kaybı gibi zararlı yönlerini inkâr etmek mümkün değildir, bu konuya dair çok sayıda araştırmanın vurguladığı gibi çekici ve eğlenceli hizmetleri ile öğrenciye ödev ve çalışma zamanını unutturabilmektedir. ${ }^{\text {iii }}$ Aşırı oranda sosyal medya kullanımı, teknolojiden yararlanma açısından olumsuz nitelendirilebilecek bir bağımlılık meydana getirmekte, ahlaki ve kanuni değerlere aykırı yıkıcı fikirlerin dolaşımına zemin hazırlamaktadır. Kendini özgürce ifade etme arzusu ve içindeki duyguları aktarma isteği, günün uzun bir zaman diliminde, Facebook, Twitter ve Instagram gibi sitelerde vakit geçirmeye itmekte, öğrenciyi okuma ve öğrenme faaliyetleri yerine müzik, film ve benzeri içerikler taşıyan eğlenceli siteler aramaya yöneltmektedir. Ancak interaktif ortamların müspet tarafları menfi taraflarının çok üstündedir. Söz konusu edilen site ve ağların, öğrenim aşamalarının da önemli bir parçası olabileceklerine dair bazı özellikleri açıklamak amacıyla aşağıdaki maddelere yer verilmiştir: 
- Eğitimin kişiselleştirilmesi: Öğrenci, kendine özgü metotlarla bilgi edinmekte ve öğrenmektedir.

- Alternatif olarak, tercih özgürlüğü: Öğrencinin eğitim sürecini tamamlamak ve nihai hedefini gerçekleştirmek için eğitmen ve eğitim ortamını seçme hakkı bulunmaktadır.

- Sosyal Medyada verilen eğitim hizmetleri, eğitmen / öğretici konumundaki akademik çevrelerin öğretim ve öğrenime dönük isteklerini karşılamak amaçlı şekillenen ve bu ihtiyaçların giderilmesi için başvurulan bir yoldur.

- Sosyal Medya araçlarının uzaktan eğitimde kullanımı, geleneksel eğitimin eksikliklerinin giderilmesine büyük bir katkı sunmaktadır. ${ }^{\text {iv }}$

- Uzaktan eğitim, bilgi birikimini arttırmak isteyenlere sunduğu avantajlarla örgün eğitim imkânını kaçıranlar için bir fırsat kabul edilmektedir.

- Çeşitli kaynakların temin edilememesi sorununu ortadan kaldırarak, öğrenciler arasındaki maddi sınıf farklılıklarını yok denecek derecede azaltmaktadır.

- Yöntem çeşitliliği: Elektronik ağlar, siteler ve sanal üniversitelerin tasarım ve temalarında uygulanan yeni teknolojiler, öğretmenin değişik yöntemler kullanılmasına olanak sağlamaktadır.

- Katılımcılık ve tamamlayıcılık içerisindeki atmosfer, bireysel ve sosyal öğrenmeyi gerçekleştirmektedir.

- Öğretim süreci aynı zamanda öğrenim içeren bir formata dönüşmektedir.

- Sosyal Medya ağları, kişisel yetenek ve özelliklerle öne çıkmak isteyen bireylerin dinamik alanı olup, öne çıkma çabaları yapıcılık, diyalog, paylaşım, üretkenlik ve işbirliği olarak ortaya çıkmaktadır.

- Reklam, duyuru takibi ve eğitim süreci ile ilgili projelerin yürütülmesinde söz konusu araçlardan faydalanılmaktadır.

- Yaratıcılığı teşvik: Öğrencilerin bilgiye ulaşmak için birçok yol geliştirmesini teşvik etmektedir.

- Bilgi paylaşımı, karşılıklı tartışma ve eleştiriler, öğrencilerin becerilerinin artmasına ve güçlenmesine yardımcı olmakta, tarafların birbirine aktardığı veriler, bilgi edinmek ve yeni bulgulara ulaşmak için uygun ve motive edici bir ortam sağlamaktadır. ${ }^{\mathrm{V}}$

- Bilgi ve verilerin belirli bir gruba has olmadıkları, ortak kullanıma ait kamu malı olduğu şeklinde bir yaklaşım ortaya konmaktadır.

- Eğitim ve öğretimde katılım ve etkileşim esası, bu platformlarda öğreneninde bilgiye katkısını kaçınılmaz kılmaktadır. ${ }^{\mathrm{vi}}$ 
- Eğitim müfredatının içeriği ve hazırlanmasında öğrencileri de sürece dâhil etmektedir. $^{\text {vii }}$

\section{Sosyal Medya ve Türkiye’de Arapça Öğretimi}

Son zamanlarda Türkiye'de Arapça öğretimi için birbirinin devamı şeklinde yayınlanan çok sayıda program oluşturulmaktadır. Ağırlıklı olarak İslami medreselerdeki geleneksel açıklama metodunu uygulayan Türk asıllı öğreticiler tarafından hazırlanan bu programlarda, çoğu zaman farkında olunmadan dilbilgisi konuları gereğinden çok işlenmekte, Arapçayı iletişim dili olarak öğrenecek bir öğrenciye, ihtiyaç duymayacağı, sarf, nahiv ve belagat kurallarıyla ilgili felsefî yorum veya tartışmalar öğretilmektedir. ${ }^{\text {viii }}$ Yine söz konusu bağlamda ana dili Arapça olanlara kendi ülkelerinde ders vermeye alışkın oldukları için yabancılara eğitim verme hususunda çok tecrübeli olmayan bazı Arap asıllı öğreticilerinin buna benzer çabaları da vardır. Bu siteler, Arapçayı öğrenmek isteyenlere çeşitli faydalar vermekte ancak istenen seviyede bir akademik destek ortaya koyamamaktadır. Bu sebepten evrensel eğitim yöntemine bağlı kalınması için düzenlenmesi ve geliştirilmesi gereken bir takım eksiklikler mevcuttur.

Doğru iletişimi sağlayacak düzeydeki dilbilgisi öğretimi kuşkusuz Arapça öğrenimini kolaylaştıracaktır. ${ }^{\text {ix }}$ Arapça bölümünden YDS'ye giren bir öğrenci, dilbilgisi kurallarını kullanarak birçok soru çözebilecek veya doğru cevap seçeneklerini azaltabilir. Ancak dilbilgisi kurallarını maddeler halinde ezbere sayabilecek özellikte olmasına rağmen dilbilgisi kurallarına odaklanması, sorulardaki inceliği görememesine sebep olmaktadır. Yapılan araştırmalar, Arapça öğretiminde başarısız olunduğunu ve bu başarısızlığın \%82 oranında yöntem, kitap seçimi ve öğretmen yetersizliğinden kaynaklandığını ortaya koymuştur. ${ }^{\mathrm{x}}$

\section{Türkiye’de Arapça Öğretimi Sitelerine Yönelik Notlar}

Türkiye'de ana dili Arapça olmayanlara bu dilin öğretimi için açılan siteler kuruluş biçimleri açısından farklılaşmaktadır. Bazı adresler, özel kurumlara, şirketlere aitken kimi elektronik ortamlar ise şahsidir. Söz konusu araçlar ve benzerlerinin lisan eğitimine dair sunduğu hizmetlere ilişkin geçerli olabilecek bazı genel notlar olarak şu hususlar dile getirilebilir:

- Bilimsel konuların, bölümsel ve aşamalı olarak sunulamaması.

- İnternet sitelerinin tasarımında işlevsel ve çekici temaların eksikliği. 
- Öğrencilerin ileri seviyelerde ihtiyaç duyduğu bilgileri kapsayan bilimsel içeriklerin az olması veya bulunamamasından kaynaklı görülen yetersizlik.

- Sesli uygulamalarda, harflerin telaffuzu ve genel videolarda orijinal olmayan materyallerin kullanmas1.

- Kullanılan bilimsel içeriklerin sürekli olarak yenilenmemesi.

- Öğretim sürecinde, öğrencilerin bilgi düzeyine bağlı kalınmadan, kavrama ve algılama durumları söz konusu edilmeden çok ileri seviyede ders vermekte 1srarcı olunması.

- Derslere yönelik alıştırma ve üniteler arası geçişlerde, belirli standartlardan yoksunluk, nitelik ve nicelik bakımından uyumsuzluk olması.

- Değerlendirme ölçütlerinin güçlü olmayışı ve devamlılığı teşvik eden unsurların yokluğu (Örn: Başarı belgesi veya sertifika hazırlama.)

- Eğitim programının yayınlandığı site, forum veya sosyal medya hesabının bazı nedenlerden dolayı kurucu veya kuruluş tarafından sonlandırılması.

\section{Öğretimde Aktifliği Artıran Faktörler}

İçerisinde bulunduğumuz çağın en bariz özelliklerden bir tanesi tarih boyunca bize sunmadığı iletişim imkânlarını bugün sunuyor olmasıdır. İletişim modellerinin sayısı artmış, bu alanda başvurulan yöntemler gelişmiş ve etkileşim içeren uygulamaları olan değişik araçlar oluşturulmuş ve de icat edilmiştir. Bilişsel açıdan değerlendirdiğimizde, teknoloji ve bilgi sistemleri, yoğun ve hızlı aktarım ile toplu etkiler oluşturan ileri bir seviyeye ulaşmıştır.

Bilgi artık çok çeşitli yollarla edinilmekte, büyük bir hızla ve aynı anda birçok yere ulaşabilmektedir. Sesli ve görsel medya ile tasarımlardaki renk seçimi bile eğitim süreci aşamalarındaki reaksiyonu artırmaktadır. Öğretime yönelik İnternet siteleri ve farklı uygulamalar, etki ve tepki dozajını arttırmak amaçlı kullanılabilecek oldukça esnek bir yapıya sahiptirler. Dijital alan, bilimsel içeriklerle birlikte Arapça eğitimini tamamlayıcı bir yönde, bilimsel teoriler ışı̆̆ında teknolojiyi kullanarak yeniden oluşturulup, düzenlenmelidir. ${ }^{\mathrm{xi}}$

Elektronik ortamlar üzerinden yürütülmesi planlanan ideal Arapça eğitimi, dinleme, konuşma, okuma ve yazma becerilerini iletişim ve etkileşim temelli bir biçimde geliştirmeyi hedeflemekte ve bu noktada gerek iyileşen araştırma olanakları gerekse kültürel dönüşümü 
hesaba katarak, bütün insanlara uyabilecek bilimsel ve metodik bir görüş benimsemeye çalışmaktadır. Aşağıda bu tür bir öğretimde bulunması zorunlu görülen bazı maddeler yer almaktadır.

- Elektronik eğitim sistemlerinin yeniliklerini, kaliteli bir sunum ve kullanım esnekliği/kolaylığı standartları uyarınca değerlendirmek.

- Bilimsel içerikleri, lisan öğretimi hususunda yeni eğilimleri esas alarak, öğrencilerin seviyelerini ve beklentilerini gözeten bir üslupla düzenlemek.

- Öğrenim sürecinde aşamalılık ilkesine göre her beceriyi birikimle oluşturma prensibine riayet eden bir tarzda, değişik stratejiler kullanılarak doğru ve ilgi çekici bilgiler sunmak.

Öğrenenlerin performansını yansıtan, ilerleyişlerini değerlendiren, her becerinin gelişimini hassasiyetle izleyen net ve yararlı ölçüm yöntemleri sağlanmalıdır. Ana dili Arapça olmayanlara Arapça öğretmeye yönelik sitelerin aktifliğini arttırmak amacıyla üç esasa özen gösterilmelidir:

1. Bilişsel / Bilgisel Referans

2. Uygulamalı Bilgi

3. Etkileşimsel Yap1

\section{Bilişsel / Bilgisel Referans}

Arapça eğitimine önem veren elektronik ortamların belirli bir sayıya ulaşmasına ve söz konusu lisanın öğretimini teknolojik ortamlarla ilişkilendirmeye dönük bireysel ve kurumsal çabalara karşın bu alanda programın kendisi üzerinde inşa edileceği bilimsel ve teorik bir temel tespiti zorunlu ve acil bir ihtiyaç olmayı sürdürmektedir. Daha önce özellikleri belirtilip, aşağıda adları verilen siteler ve benzerlerinin bilimsel içerikleri incelendiğinde güvenilir, bilimsel ve teorik bir düşünceye dayanmadıkları için kuruluşları esnasında bilgiye dair net bir referanstan yoksun oldukları gözlenmektedir. ${ }^{\text {xii }}$

İlgili platformların çoğunda ilmi muhtevanın bilişsel-bilgisel referans ölçütünü yitirmesine bağlı olarak şu durumlar ortaya çıkmıştır:

- Sitelerin kuruluş anında, hedef ve girdilerinin net olmayışı.

- Içerik tasarımında öğrenmeye ilişkin amacın net bir şekilde saptanmaması. 
- Hedefler ve uygulamalar arasında açık bir ilişki olmamasından ötürü, sonuç ve çıktıların birbirine uygun olmamas1.

- Öğretime dair dijital içeriğin zayıflığı: Bu sitelerde sunulan eğitim materyalleri az olup, genellikle kapsamı ve sunduğu bilgiler bakımından güçlü değildir. Bu düzeyde öğretilen Arapça, hayatın değişik alanlarını ifade etmeye yeterli değildir. xiii Düzeylerin siralanmasında uluslararası standartların gözetilmemesi ve seviyelere uygun derslerin hazırlanmaması da göze çarpan diğer bir husustur. Kuramsal çerçeve ve onun uygulama koşullarına dair belirgin bir anlayışın yokluğu, öğrenme ve öğretme sürecinde kişisel eğilimleri baskın hale getirmektedir.

- Uygulamalı filolojik araştırmaların gelişimine ayak uyduramamak: Bu eksiklik yabancı dil yeteneğini ölçen sınavların ve esas alınan değerlendirme ölçütlerinin, kelimeleri salt dilbilgisi formatları üzerinden yargılayıp, ifade ve iletişimdeki rollerini ikinci plana atmasıyla ortaya çıkmaktadır.

- Aktif katılım ve eğlencenin yokluğu: Dil öğretiminin sadece kuralları ve sözcüklerin ezberini aşan bir biçime sokulması; yeni toplumları tanıma ve onlara uyum sağlamayı, farklı medeniyet ve kültürlere açılmayı içerecek şekilde genişletilmesi gerekmektedir.

- Değerlendirme standartlarının ve ölçüm temellerinin bulunmaması: Kelime, kalıp, üslup ve dil öğreniminin dört becerisi (konuşma, okuma, yazma ve işitme) ile ilgili diğer konularda belirgin ve doyurucu kistaslar yoktur. ${ }^{\text {xiv }}$

- Becerilerin arasında tamamlayıcılık ve düzen olmayışı: Bu durum, dil öğreniminin doğal seyri hakkındaki vizyon eksikliğinden, orta ve ileri düzeylerde güçlü bir başarı sağlanması için ilk seviyelerden itibaren konuşma ve dinleme becerilerine odaklanan uygulamalı bir yaklaşım bulunmamasından kaynaklıdır.

Elektronik ortamda bilimsel içeriklere yönelik metot yapılandırması için bilişselbilgisel referans belirlenmesi amacıyla, yabancı dil eğitiminin uluslararası standartlarına başvurulabilir. Bu noktada Amerikan Yabancı Dil Öğretimi Konseyi’nin (American Council of Teaching Foreign Languages - ACTFEL) benimsediği ölçütlerden ve internet adresinden (https://www.actfl.org) faydalanılabilir. Aynı şekilde Avrupa'nın lisan öğretimi konusunda ortak referans noktası olan CECR (Cadre Européen Commun de Référence pour les Langues) adlı kurumun sitesinden (http://www.coe.int/T/DG4/Linguistic/Source/Framework_FR.pdf) yararlanılabilir. Bu iki kurumun kuramsal çerçeveleri hali hazırda yaygın olup, ilgili konuda geniş pratikler öngörmektedir. $\mathrm{Bu}$ müesseselerin yöneldiği teoriler, belirli formatlar ve 
yöntemler temelinde kişisel eğitimden ziyade, kelime ve kalıpların işlevlerine ve amaca ulaşma adına, çeşitliliğe dayalı olarak dil becerilerini geliştirmeyi hedeflemektedir.

\section{Uygulamalı Bilgi}

Yabancı dillere yönelik eğitim sitelerinde var olan teknik uygulamalar, bilişim teknolojilerinin kullanılmasına olanak sağlayan pratik ve verimli bir saha oluşturmakta ve lisan eğitiminde bilgi sistemlerinden yaygın olarak faydalanılmasına imkân tanımaktadır. Öğrenenlerin ihtiyaç ve akademik hedeflerini gözeten etkileşim temelli bir edinim ortamı sunmak yoluyla, farklı eğitim amaçlarına yanıt veren, zengin ve düzenli içerikler tasarlamada, uzman ve filologlara yardımcı olmaktadır. ${ }^{\mathrm{xv}}$

Bilinen dijital uygulama süreci, teknik uygulama esasları ve ona ait öğretim stratejilerini belirlemenin yanında, teorik öğretim ilkeleri ve pratik uygulama kurallarına ihtiyaç duymaktadır. Söz konusu bilgi çeşidine pek çok sitede rastlanmamakta ve bu konuda çok sayıda eksiklik bulunmaktadır.

Yöntem, program ve maddelerin tasarımında zayıflık: Bu durum sonucunda bilimsel metodun inşasında bir çeşit eksiklik görülmekte, elektronik eğitimdeki arama-araştırma, iletişim ve keşif imkânlarının verdiği öğrenme özgürlüğünün önüne, sınırlandırma ve kayıt altına alma gibi sorunlar oluşturmaktadır. Tasarım, program ve yöntemlerin düşünsel boyutlarını ve teorik altyapısını gözler önüne sermektedir. ${ }^{\text {xvi }}$ Yeterli ağların ve linklerin olmaması nedeniyle, bilgiye ulaşımın kolay olmayışı; renk, ses ve sunum aygıtları açısından çekici olunamaması gibi.. Söz konusu durum, ziyaretçilerin bıkkınlığına ve ziyaretçi trafiğinin azalmasına yol açmaktadır. Bilişsel-bilgisel referans hususunda uluslararası standartlara başvurup yöntemlerin düzenlenmesi ve katılımcılık içeren SCORM (Sharabla Content Objekt Reference Model / Paylaşılabilir İçerik Nesne Referans Modeli) modeline benzer elektronik formatların üretilmesi gereklidir. Bu bağlamda kastedilen standartlar, içerik yönetim süreci, kaliteli programlar oluşturup, fayda sağlamayı önemseyen anlayışın özellik ve ölçütlerinin toplamidir.

\section{Etkileşimsel Yapı}

Etkileşimsellik, bilgi edinme sürecinin alıcı, gönderici, öğrenimsel içerik ve sunum aygıtları şeklinde ifade edilebilecek, taraflar arasında karşılıklı tesirlere izin veren, farklı sistem ve araçlar kullanan, elektronik eğitimin özelliklerinden biridir. Bu olgu kapsamında 
sanal enformasyon çalışmalarında olması gerektiği var sayılan en belirgin maddelerden biri, malumatların canlı ve hızlı bir şekilde aktarımıdır. Bu seri işlem de farklı türlere ve üstün özelliklere sahip olan bilgi sistemleriyle, özgün maddeler/dersler oluşturulmasını sağlayan, bireysel kazanımları güçlendirmekle ilgilenen, yüksek kalitedeki çeşitli iletişim araçlarıyla gerçekleştirilmektedir.

$\mathrm{Bu}$ kavram etrafındaki terminoloji, karşılıklı tepki alımı uyarınca dil öğretimini benimseyen, dilin birbirinden farklı anlamsal ve işlevsel boyutlarını ortaya çıkarmaya çalışan uygulamalar çerçevesinde, araçların ve teknolojilerin görevlendirme biçimleri ile ilgilenmektedir. Söz konusu bağlamda çok sayıda çalışma ve etkinlik düzenlenerek, lisan alıştırmaları için yeterli firsat sunumunun sağlanması ve böylelikle doyurucu bir eğitim düzeyine ulaşılması hedeflenmektedir. ${ }^{\text {xvii }}$

$\mathrm{Bu}$ özelliğin korunması adına, elektronik eğitim sistemlerini geliştirenlerce, farklı bilgilerin çok çeşitli yollarla sunulmasına ve elde edilmesine önem verildiğinden, geleneksel sunum ve anlatım biçimlerine bağlı kalınmamaktadır. Sabit ve değişken biçimlerin bir arada olduğu düzenler içeren, çok sayıda türden metinlerin okunma desteğine ek olarak, seslendirme uygulamaları ile birlikte açıklamalar sunan, farklı teknik ve aygıtların oluşturulması için çaba sarf edilmektedir.

$\mathrm{Bu}$ çerçevede anlatılan bilgisel sistemler bir yönden kullanıcıların istek ve ihtiyaçlarına diğer bir taraftan da filolojik araştırmalarda benimsenen en son ilke ve esaslara göre verilerin ele alınmasını, iletimi, yeni ve etkili çok sayıda yolla sunulmasını içeren bir tarzda dil öğretimi konusunda da görevlendirilmektedir. Ayrıca ilgili sistemlerin söz konusu kapsamda katılımcılık, işbirliği, tepki alımı ve bilgi paylaşımı temelli bir etkileşimselliği gerçekleştirecek biçimde, teknolojik aygıtları ve öğretim uygulamalarını birleştirmesi istenmektedir. Etkileşimsel aktivite; hareket, ses, metin ve renkler gibi dikkat çekici faktörlerin birbirini tamamlayan biçimde kullanılmasını gerekli kılmaktadır. Böylesi bir harmoni karşılıklı tesir olgusunu derinleştirmekte, seçim olanaklarının, esnekliğin, eş zamanlı olan ve olmayan metotların dairesini genişletmektedir.

Dil eğitiminde Sosyal Medyanın kullanılması çeşitli kolaylıklar sağlamaktadır. Örneğin, öğrenci istediği öğreticiyi seçebilmekle beraber, mesafe kaygısı taşımadan başka bir 
ülkedeki daha deneyimli bir öğreticiyi de tercih ederek öğrenim sürecini devam ettirebilmektedir

Arapçayı akıcı bir şekilde konuşabilmek için sürekli olarak pratiğe ihtiyaç duyulur. Öğrenci, sosyal medyanın sunduğu imkânlarla ana dili Arapça olan hoca ve öğrencilerle karşılaşma, öğrenmekte olduğu dili pratikte de uygulamaya dökme şansına sahip olur.

Engelli öğrenciler için Sosyal Medya aracılığıyla verilen özel dersler, hareket kabiliyet ve alanı sınırlı bu öğrencilere büyük kolaylık ve katkı sağlamaktadır.

Klasik eğitim uygulayan bazı dil enstitülerinin öğrenci için oldukça sıkıcı ve yetersiz olan öğretim yöntemleri, Sosyal Medya araçlarının sağladığı daha rahat ve eğlenceli eğitim ve öğretim yöntemleri ile aş1labilmektedir. Eğitim ve öğretim sürecinde çevrimiçi derslerin icra edilebilmesi için bilgisayar kullanımı önem arz etmektedir. Birçok alanda olduğu gibi bilgisayarların eğitim amaçlı kullanımı da giderek yaygınlaşmaktadır. Bilgisayarı uzaktan eğitim amaçlı kullanan kurumlarda bilgisayarlı öğrenmeden sıkça söz edilmektedir. Uzaktan eğitimde bilgisayarlı öğrenme, bilgisayarlı öğrenme kaynaklarıyla gerçekleşmektedir. Bilgisayarlı öğrenme kaynakları öğrenme sürecinin daha kolay ve eğlenceli hale gelmesini sağlar. ${ }^{\text {xviii }}$

Bilgisayarlı öğrenme kaynakları uzaktan eğitim öğrencilerine ve uygulayıcılarına genel olarak bazı önemli faydalar sağlamaktadır. Bilgisayarlı öğrenme kaynaklarının sağladığı başlıca faydaları şu şekilde ifade edilebilir.

Bilgisayarlı öğrenme kaynaklarıyla bilgi edinme, öğrenciyi bilgiye, geleneksel yöntemlerle ulaşacağı zamandan çok daha kısa bir sürede ulaştırır. Etkileşimle, çoklu ortam sunumlarının uyarıcı etkisi öğrenmeyi kolaylaştırır. Öğretim, uygun olan yer ve zamanda sunulur. Planlama esnek olabilir. Öğrenciler daha önceden kazandıkları bilgi ve beceriler için zaman kaybetmez. Ön bilgiler anlaşılıncaya dek, öğrenciler bir sonraki evreye geçmek zorunda değildirler. Öğretmenlerin ders ortamından çıkmalarını sağlar. Öğretmenler böylece öğrencilere bireysel olarak yardım edebilmek için daha fazla zaman bulur. Ayrıca dersi güncelleştirmek ve bunu uzaktan eğitim kurumunun koşullarına uygun hale getirmek için de daha fazla zamanları olur. Otomatik hale gelen kayıt tutma sayesinde öğrenci gelişimi daha kolay ölçülür. Dersler düzenli ve kendi mantığında sunulur. Ellerinde yeterli kayıt bulunan 
uzaktan eğitim uygulayıcıları, öğrencinin bulunduğu durumu kolayca anlayabilir. Çalışan öğrencilerin işten ayrılma süresi azalır ve üretkenlik kaybı yaşanmamış olur. Öğrencilerin eğitim-öğretim performansları artar. Bir süre sonra uzaktan eğitim uygulamasının maliyeti, eğitim-öğretimde yapılan tasarruflardan elde edilenden daha az hale gelir.

Bilgisayarlı öğrenme kaynaklarının bazı olumsuzlukları da mevcuttur. Bunlardan bazıları şunlardır: Derse dayalı öğretimi planlama ve geliştirmeyle karşılaştırıldığında, bilgisayarlı öğrenme kaynaklarıyla öğrenmenin başlangıç maliyeti yüksektir. Öğrencilerin kullanmaları gereken donanım fiyatları öğrenci bütçesi açısında yüksektir. ${ }^{\text {xix }}$

Bilgisayar destekli öğretim olanakları, Arapça dil eğitimi için de çevrimiçi olarak sunulmaktadır. Ahmet Yesevi Üniversitesi bünyesinde faaliyet gösteren Çimkent ile diğeri Kazakistan'ın Türkistan şehrindeki yerleşkesinde var olan iki tane "Uzaktan Eğitim Fakültesi" mevcuttur. Koordinasyon fakülteleri konumunda olan bu fakültelerde esas öğretim, örgün eğitim veren fakültelerin ilgili bölümlerinin öğretim üyeleri tarafından aynı müfredat programı uygulanarak gerçekleştirilmektedir. Çimkent Uzaktan Eğitim Fakültesi'nin eğitim dili Kazakça-Rusça olup, Türkistan Uzaktan Eğitim Fakültesinin eğitim dili ise Kazak Türkçesi-Türkiye Türkçesidir.

Uzaktan Eğitim Programları kapsamında Arapça öğretimi, alanında uzman öğretim üyeleri tarafından Türkiye Türkçesiyle gerçekleştirilmektedir. Bu sayede dünyanın dört bir yanından derse iştirak eden öğrenciler Arapça öğrenme imkânı bulabilmektedir.

TÜRTEP'in (Türkiye Türkçesiyle Uzaktan Eğitim Programı) öğrencilerine, çağımızın yüksek bilişim teknolojilerine dayanan web tabanlı internet ortamında kaliteli bir eğitim vermeyi amaç edindiği görülmektedir. $\mathrm{Bu}$ sistemin tercih edilmesinin nedeni, klasik eğitimdeki sınırlı öğrenci sayısı, ayarlanabilir zaman ve mekân imkânı sunan, herkesin katılabileceği öğretim imkânı olan daha etkili ve verimli bir sistem olmasıdır. Bu sistemle eğitim, 24 saat canlı tutulmakta ve öğrenciye 24 saat bilgi alma imkânı yaratılmakta, dinamik bir şekilde danışman öğretim üyeleriyle sürekli iletişim imkânları sağlanmaktadır. ${ }^{\mathrm{x}}$

\section{Sonuç}

Anadili Arapça olmayanlara Arapça öğretimi için açılan

- $\quad$ http://www.onlinearabic.net/ 
- http://www.arapcaegitimi.com/

- http://www.ilyasucar.com/arapca-ogreniyorum/

- https://www.busuu.com/tr/a/b/arapca-ogrenmek

adlı siteler incelendiğinde, bu alanda ortaya konan övgüye değer çalışmalar olduğu görülmektedir. Ancak söz konusu çalışmaların, dilbilimin teorik temellerinin uygulanmasına ve elektronik eğitimin, teknoloji ile öğrenim temelli standartlara dair derin anlayış düzeyine henüz ulaşmamış, geç atılan adımlardan oluştuğu görülmektedir. Böylelikle sanal ortam ve araçların yardımı ile Arapça eğitiminde, istenen düzeyde bir aktiflik sağlanamadığı, beklenen faydaların hala edinilemediği ortaya çıkmaktadır. Düzenleyici ve yöntem ile ilgili bazı stratejilerin belirlenip, benimsenmesi ve bu yönde sağlam bilimsel temellerin tespiti sorunu devam etmekle beraber, buna iliş̧in bir takım öneriler şunlardır.

Öğrencilerde istek ve keyif uyandıracak program ve müfredatlar hazırlanmall, bireylerin Arapça konuşma ve iletişim ihtiyaçları karşılanmalı, öğrencinin bağlı olduğu medeniyet ve kültürü ile mevcut bulunduğu toplumdaki pozisyonu arasında doğrudan bağlantı kurmasına imkân verilmelidir.

Katılımcıların, dil yeteneklerini belirleyen çalışmalar düzenlendikten sonra seviye geliştiren etkileşimli metotlarla aşamalı olarak akıcı konuşmaya yönlendirilmeleri gerekmektedir.

Çeşitli dil ve kültür faaliyetleri organize edilmeli, öğrenmeye katılanlar sürece ısındırılmalı, sosyal ve kültürel bağlamda kelimelerin kullanılışına tanıklık etmeleri sağlanmalıdır. Bu çalı̧̧mada ele alınan üç esasın (bilişsel-bilgisel referans, uygulamalı bilgi ve etkileşimsel yapı) gözetilmesi ile birlikte Arapçayı, ana dili Arapça olmayanlara, elektronik ortam ve internet siteleri aracilığılla öğretmek mümkün olacaktır. Böylelikle öğrencinin öğrenim ortamındaki eğilimlerine önem veren, onu öğrenme sürecinin temel değişkeni sayan, işlevselliği arttırılmış ve iletişimsel hassasiyetlerine cevap verilmiş olunacaktır. 


\section{Kaynakça}

Avde, M. (2014), Davru şebakat et-tavâsul el-ictimaî fi'l-ameliyye et-ta'limiyye, Filistin. $\quad$ http://www.elearning.iugaza.edu.ps/enrag/article.php?artID=34 (Erişim tarihi: 12.12.2018).

Avkel, H. (2009), et-Tevcihu'l-fenni li'l-vesâil et-ta'limiyye el-hadîse, http://www.atinternational.org/forums/showthread.php?t=7152 (Erişim tarihi: 12.12.2018).

Candemir, D. (2006) “Arapça Öğretiminde Yöntem Orijinli Problemler ve Çözüm Önerileri” Nüsha Şarkiyat Araştırmaları Dergisi, 21/Bahar, s. 80.

Doğan, A. (1979), Her Yönüyle Dil: Ana Çizgileriyle Dilbilim, Türk Dil Kurumu Yayınları, Ankara.

El-Mukdedî, G. (2013), Sevratu'ş-şebekât el-ictimâiyye (mahiyyetu mevâkii'ttevâsuli'l-ictimaî), 1.bask1, Dâru'n-nefîs li'n-neşr, Amman.

El-Hâdî, M. (2005), et-T'elîm el-eliktronî 'abra şebeketul-internet, Kahire.

El-Kandelcî, İ. (2013), el-i'lâm ve'l-malûmât ve’l-internet, Daru'l-yâvûzî, Amman.

El-Yûbî, H. (2017), Effectiveness of web sites in teaching Arabic to non - native speakers, Riyad.

Eş-Şimmerî, A. (2011), Keyfiyyetu'l-istifâde mine'ş-şebekât el-ictimâiyye fi'ttalîm, http://abdulkrem556.blogspot.com/2011/12/blog-post_17.html (Erişim tarihi: 12.12.2018).

Fran Freer, N. and Manguillon Alfonso J. (2011), Content Management for ELearning, Springer, electronic edition.

Halefullah, C. (2013), et-Tâlîm bi’ş-şebekâti't-tevâsul el-ictimâî, http://kenanaonline.com/users/azhar-gaper/posts/517501 (Erişim tarihi: 12.12.2018).

İlut, Divayt, Davidson; Peter, Vekom, Kristin (2008), Council of Europe Language Policy Portal, (Demiği Çev.). İdaretu'n-Neşr el-İlmî, Riyad.

Kandîl, A. (2006), et-Tedrîs bi’t-teknolojiye el-hadîse, Kahire.

Kâtît, Ğ. (2009), el-Hâsûp ve turûk't-tedrîs ve’t-takvîm, Amman.

Kaya, Z. (2002), Uzaktan Eğitim, Pegem A Yayınları, Ankara.

Levi, M.; Koyıl, C. (2010), (ez-Zehrani Çev.). Eb‘âd Te‘allumi’l-luğa bimusaadeti’lhâsûb el-‘ilmî, İdaretu’n-Neşr el-İlmî, Riyad. 
Mansûr, A. (2014), Esasiyyāt Teknūlūciyā et-Terbiye-Eğitim Teknolojilerinin Esasları, Eğitim Fakültesi, Dimyat, Kahire.

Murat G. (2014), Yabancı Dil Öğretimi ve Dünden Bugüne Türkiye’de Arapça Öğretimi, Karadeniz Teknik Üniversitesi İlahiyat Fakültesi Dergisi, bilgi. (güz, 1, s. 193 -211), Trabzon.

Richards, G. (2011), Performance and Competence in Teaching Language, Cambridge University Press New York.

Simonson M.; Smaldino S., Albright M. and Zvacek S. (2006), Teaching and learning at a distance, foundations of distance education, in (Theory and

Distance Education, The need for Theory).

http://www.turtep.edu.tr.

${ }^{\text {i } E l-M u k d e d i ̂, ~ G . ~(2013), ~ S e v r a t u ' s ̧-s ̧ e b e k a ̂ t ~ e l-i c t i m a ̂ i y y e ~(m a h i y y e t u ~ m e v a ̂ k i i ’ t-t e v a ̂ s u l i ' l-i c t i m a i ̂), ~ 1 . b a s k ı, ~}$ Dâru'n-nefîs li'n-neşr, Amman, s. 71-72-73.

ii El-Kandelcî, İ. (2013), el-i'lâm ve'l-malûmât ve'l-internet, Daru'l-yâvûzî s.323

iii El-Hâdî, M. (2005), et-T'elîm el-eliktronî 'abra şebeketul-internet, Kahire, s.103.

${ }^{\text {iv }}$ Kâtît, Ğ. (2009), el-Hâsûp ve turûk't-tedrîs ve't-takvîm, Amman, s.34.

v ‘Avde, M. (2014), Davru şebakat et-tavâsul el-ictimaî fi’l-ameliyye et-ta‘limiyye, Filistin.

vi 'Avkel, H. (2009), et-Tevcihu'l-fenni li’l-vesâil et-ta ‘limiyye el-hadîse.

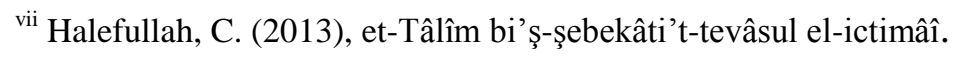

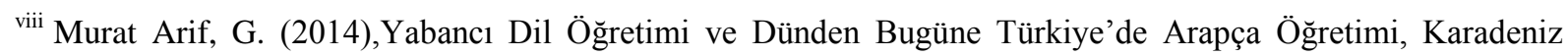
Teknik Üniversitesi İlahiyat Fakültesi Dergisi, s.206

ix Doğan, C. “Arapça Öğretiminde Yöntem Orijinli Problemler ve Çözüm Önerileri” Nüsha Şarkiyat Araştırmaları Dergisi, 21 (Bahar 2006), s. 80.

10. Doğan A. (1979), Her Yönüyle Dil: Ana Çizgileriyle Dilbilim, Ankara: Türk Dil Kurumu Yayınları, I,58.

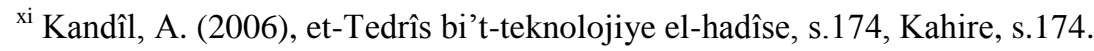

${ }^{x i i}$ Simonson Michael, Smaldino Sharon, Albright Mechael and Zvacek Susan (2006), Teaching and learning at a distance, foundations of distance education, in (Theory and Distance Education, The need for Theory), see P.40

xiii Levi, M.; Koyıl, C. (2010), (ez-Zehrani Çev.). Eb âd Te'allumi'l-luğa bi musaadeti'lhâsûb el-'ilmî, İdaretu'nNeşr el-İlmî, Riyad, 399-400.

${ }^{\text {xiv }}$ Illut, Divayt, Davidson; Peter, Vekom, Kristin (2008), Council of Europe Language Policy Portal, (Demiği Çev.). İdaretu'n-Neşr el-İlmî, Riyad, s. 135-136.

${ }^{\mathrm{xv}}$ El-Yûbî, H. (2017), Effectiveness of web sites in teaching Arabic to non - native speakers, Riyad, s.67 
${ }^{\text {xvi }}$ Levi, M.; Koyıl, C. (2010), s. 399-400.

xvii Richards, G (2011), Performance and Competence in Teaching Language, Cambridge University Press New York.

xviii Kaya, Z. (2002), Uzaktan Eğitim, Pegem A Yayınları, Ankara, s.193.

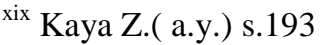

${ }^{\mathrm{xx}} \mathrm{http}: / /$ www.turtep.edu.tr 